\title{
German Experimental Hepatitis B Vaccine - Influence of Variation of Dosage Schedule, Sex and Age Differences on Immunogenicity in Health Care Workers
}

\author{
A. Krämer, D. Sommer, E.G. Hahn, and E.O. Riecken \\ Medizinische Klinik und Poliklinik, Schwerpunkt Gastroenterologie, Klinikum Steglitz, Freie Universität Berlin
}

\begin{abstract}
Summary. Of the medical staff of our hospital 217 members at high risk for hepatitis B were immunized with an experimental hepatitis $B$ vaccine and anti-HBs titers used to study the influence of two dosage schedules, age, and sex on immunogenicity. Participants were 34 years of age (mean; range, 20-61); they were divided into two groups and vaccinated three times. Group $A$ received $42 \mu \mathrm{g} \mathrm{HBsAg}$ for each vaccination. Group B received $84 \mu \mathrm{g}$ for the first and $21 \mu \mathrm{g}$ for the second and third vaccinations. The seroconversion rate was $32.7 \%$ after the first, $78.8 \%$ after the second, and $95.7 \%$ after the third vaccination. The participants who failed to produce anti-HBs titer (3 IU/1; $n=9$ ) or whose anti-HBs titers were below $50 \mathrm{IU} / 1$ $(n=31)$ were vaccinated a fourth time. Only mild side effects of injections were observed in a third of all participants, usually in the form of a sore arm.
\end{abstract}

Between groups $\mathrm{A}$ and $\mathrm{B}$ there were no significant differences as far as the seroconversion rate and anti-HBs titer were concerned. Nonresponders plus low-responders accounted for 19\%. Female participants produced a markedly higher anti-HBs titer than males, and the female/male ratio among non- and low-responders was $1: 2$; among nonresponders, $1: 2.5$. There was a negative correlation of the anti-HBs titer with the age of the participants. These results not only have practical consequences for revaccination policy, but also offer the opportunity to further study the genetic regulation

Abbreviations: anti- $\mathrm{HBc}=$ antibody to hepatitis $\mathrm{B}$ core antigen; anti-HBe $=$ antibody to hepatitis $\mathrm{B}$ e antigen; anti-HBs = antibody to hepatitis B surface antigen; HBsAg=hepatitis B surface antigen; $\mathrm{IU} / 1=$ international units per liter $\mathrm{MSD}=$ Merck, Sharp, and Dohme of the immune response to a complex peptide antigen in man.

Key words: Hepatitis B - Vaccination - Immunogenicity - Dosage - Age - Sex

The studies of Szmuness et al. [21, 22], Maupas et al. [12], Crosnier et al. [2, 3], and ReerinkBrongers et al. [18] demonstrated the safety and efficacy of active immunization against hepatitis $B$ in homosexuals, children in Senegal, hemodialysis unit staff and patients, and volunteers. These populations are not only at high risk as far as morbidity and mortality of the acute illness is concerned, but also because of chronic viral hepatitis, liver cirrhosis, and primary liver cell carcinoma conditions which to date cannot be treated effectively.

In Europe, vaccination was especially recommended for health care personnel because they are at a higher risk for hepatitis $B$ than is the normal population [4]. A non- or low-responder rate of $7 \%-10 \%$ was observed in healthy individuals, but these terms are not uniformly defined. Thus, many questions related to immunogenicity, sex and age dependence, and dosage schedule are still open for discussion in this particular group of individuals. We conducted a trial in high-risk personnel of a large medical school hospital using an experimental hepatitis B vaccine [24], when commercial preparations were not yet available in Germany and safety was of great concern. We measured anti$\mathrm{HBs}$ titers in this trial to investigate aspects of immunogenicity of HBsAg, using two different dosage schedules against age and sex differences. 


\section{Methods}

\section{Participants}

Trial participants were recruited from high-risk settings within our hospital, e.g., surgery, intensive care, hemodialysis, anesthesiology (Table 1). Inclusion criteria were: no history of hepatitis $\mathrm{B}$, negative serologic studies for all markers of hepatitis $B$ virus infection or the presence of anti-HBs or anti-HBc alone, normal transaminase levels, and written informed consent. There were 217 participants in the study. The first 110 were assigned to group A (see below), the remaining 107 to group B. Groups A and B did not show statistically significant differences in terms of numbers, sex, and age (Table 2).

\section{Vaccine}

The experimental vaccine administered in this trial consisted of purified $22 \mathrm{~nm}$ HBsAg particles $a b-$ sorbed onto aluminium hydroxide adjuvant. It was passed for clinical trials by the Ethics Committee of the Medical Department of the University of Göttingen. Not only potency, but also safety as-

Table 1. Distribution of trial participants in different high-risk areas of our hospital

\begin{tabular}{ll}
\hline Origin of trial participants & Number \\
\hline Surgery & 56 \\
Internal medicine & 47 \\
Intensive care/dialysis units & 33 \\
Anesthesiology & 24 \\
Oral surgery & 17 \\
Clinical chemistry & 10 \\
Medical students & 9 \\
Radiology & 8 \\
Pathology & 7 \\
Neurology & 3 \\
Other & 3 \\
\hline
\end{tabular}

Table 2. Assignment of participants to vaccination groups $\mathrm{A}$ and $B$. There are no significant differences in total number, sex, and age in the various groups

\begin{tabular}{llllll}
\hline & $\begin{array}{l}\text { Total } \\
(n)\end{array}$ & $\begin{array}{l}\text { Male } \\
(n)\end{array}$ & $\begin{array}{l}\text { Female } \\
(n)\end{array}$ & $\begin{array}{l}\text { Age (geometric } \\
\text { mean/range) }\end{array}$ \\
\cline { 3 - 6 } & & & & Male & Female \\
\hline Group A & 110 & 51 & 59 & $33 / 22-47$ & $30 / 21-44$ \\
Group B & 107 & 58 & 49 & $33 / 21-55$ & $30 / 20-61$ \\
Total & 217 & 109 & 108 & $33 / 21-55$ & $30 / 20-61$ \\
\hline
\end{tabular}

pects played an important role in the preparation of the vaccine. Preparation and inactivation procedures were published in detail by Thomssen et al. in 1982 and 1983. Briefly, plasma of healthy anti$\mathrm{HBe}$ positive chronic HBsAg carriers was used as a source of HBsAg. To reduce its theoretically possible residual infectivity, pure $\mathrm{HBsAg}$ was treated with formalin at the high concentration of $1: 500$ at $37^{\circ} \mathrm{C}$ for 4 days. Pepsin digestion was not applied, but in the batch used in the present study more than $99 \%$ of antigens were S-gene products and only traces of pre-S antigens could be detected [24; Gerlich, personal communication].

\section{Study Design}

The vaccination included three injections of vaccine, the first two given 1 month apart and the third given 5 months after the first vaccination. Participants in group $\mathrm{A}$ received three injections of $42 \mu \mathrm{g} \mathrm{HBsAg}$, participants in group B received $84 \mu \mathrm{g}$ for the first and $21 \mu \mathrm{g} \mathrm{HBsAg}$ for the second and third injections. Thus, the total dose was identical in both groups.

Adverse effect protocols and blood samples were obtained 3 weeks after each injection. The serum was tested for HBsAg, anti-HBs titer, anti$\mathrm{HBc}$, and aminotransferases.

Participants whose anti-HBs titer was below $50 \mathrm{IU} / 1$ after the third injection were regarded as low responders, and they were vaccinated a fourth time.

From 217 participants who were enrolled in the study, only six had to be excluded (one in group A, five in group B), all of them because of failure to appear for control studies. None of these six drop-outs had experienced notable side effects.

\section{Laboratory and Statistical Methods}

Anti-HBs titers were measured in the laboratory of Prof. Thomssen, Göttingen, by radioimmunoassay using the WHO standard as a reference. Levels of at least $3 \mathrm{IU} / 1$ were regarded as positive, and defined seroconversion. Tests for HBsAG and anti- $\mathrm{HBc}$ were performed using commercially available radioimmunoassays in the laboratory of Prof. Habermehl, Berlin. Additionally, blood samples were measured for alanine and aspartate aminotransferases using a spectrophotometric procedure, according to the optimized standard methods of the Deutsche Gesellschaft für Klinische Chemie, using commercial kits. Statistical significance of differences between means was calculated with Student's $t$-test. 


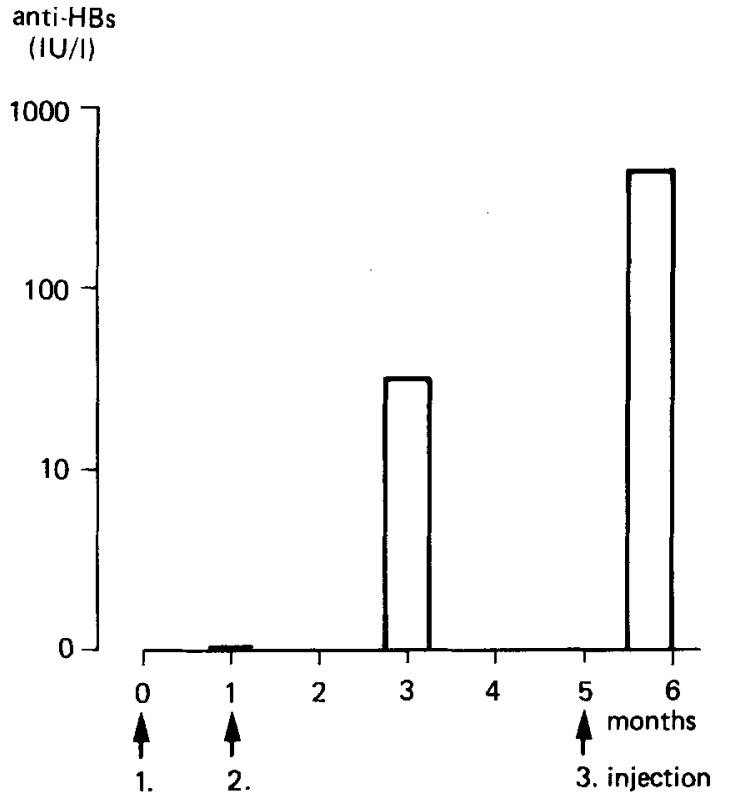

Fig. 1. Anti-HBs of all participants in the trial. Geometric means of antibody titers were $0 \mathrm{IU} / 1$ (range, 0-6220) after the first injection, $30(0-4450)$ after the second, and $428(0-137800)$ after the third injection. The differences were statistically significant, $P<0.01$

\section{Results}

\section{Immunogenicity and Revaccination}

The vaccine was highly immunogenic. Anti-HBs appeared in $32.7 \%$ of the vaccine recipients after the first, in $78.8 \%$ after the second, and in $95.7 \%$ after the third injection. Nine of 211 participants remained seronegative after the third injection and were therefore regarded as nonresponders.

The level of anti-HBs varies among the individ-

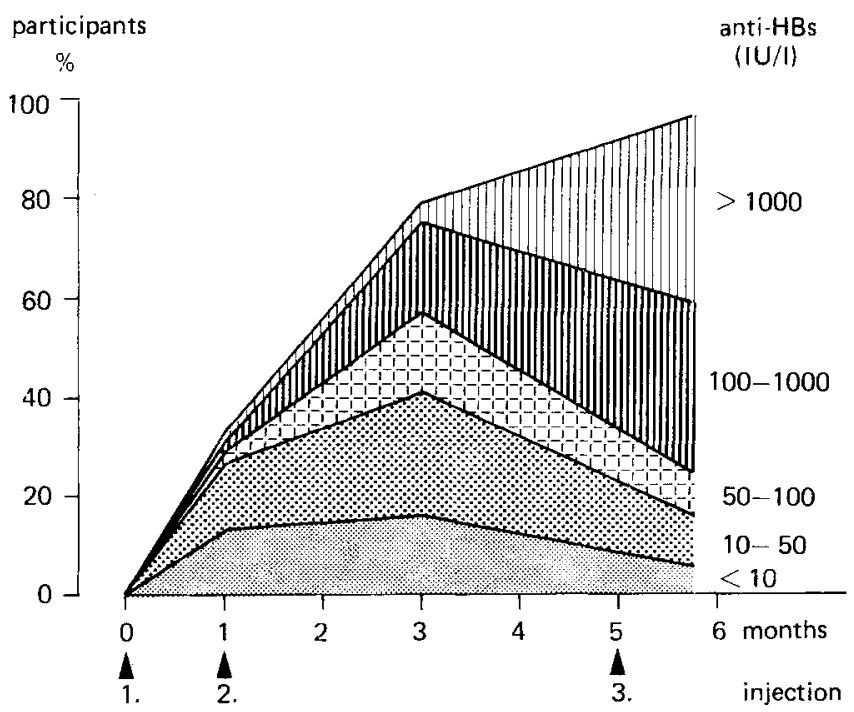

$\underset{\text { anti-HBs }}{\text { (IU/I) }}$

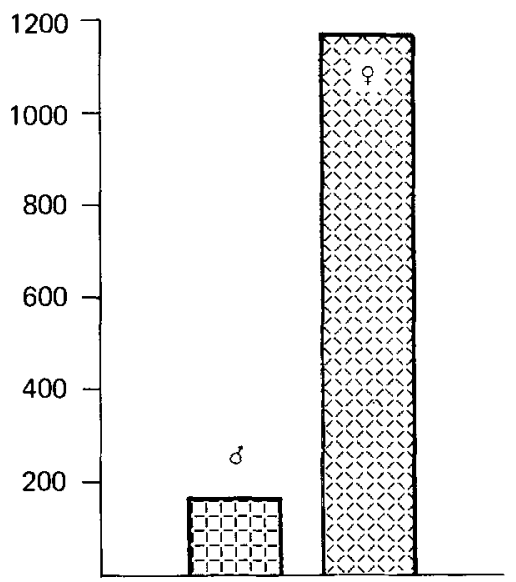

Fig. 3. Geometric means of anti-HBs after the third injection in men and women. In women, the value was $1170 \mathrm{IU} / 1$ (range, $0-137800)$; in men, $171(0-20000)$. This difference is statistically significant $(P<0.002)$. Age distribution is equal in both sexes (see Table 2)

uals over a wide range. After the first injection, the geometric mean was 0 IU/l (range, 0-6220), after the second injection $30 \mathrm{IU} / 1(0-4450)$, and after the third injection $428 \mathrm{IU} / 1 \quad(0-137800)$ (Fig. 1). The differences were statistically significant $(P<0.01)$. About $75 \%$ of the vaccine recipients had an anti-HBs titer of $>100 \mathrm{IU} / 1$, about $19 \%$ had a titer $<50$ IU/1 (Fig. 2). The group of non- and low-responders included 40 participants (12 females, 28 males), 34 of which were vaccinated a fourth time. Three female and six male individuals were nonresponders (HBsAg titer $\leq 3 \mathrm{IU} / \mathrm{l}$ ). After the fourth vaccination, six of nine nonresponders produced anti-HBs. All three remaining

Fig. 2. Ranges of anti-HBs levels. About $75 \%$ of the participants showed anti-HBs titers $>100 \mathrm{IU} / 1$ after the third injection, about $16 \%$ showed titers $<50 \mathrm{IU} / 1$ 


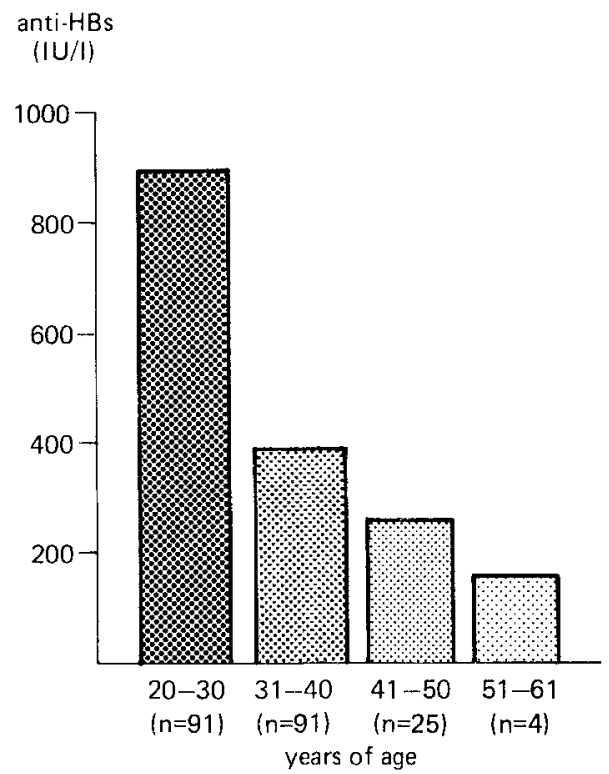

Fig. 4. Geometric means of anti-HBs after the third injection, all participants stratified for age. With increasing age the antiHBs level was lower. In the age group 20-30 years, the mean was $895 \mathrm{IU} / 1$ (range, 0-137800), in the group 31-40 years, 383 $(0-49950)$, and this difference is statistically significant $(P<$ 0.05 ). There is also a statistically significant difference between the age groups $20-30$ years and $41-50$ years. In the group $41-$ 50 years, the geometric mean was $241 \mathrm{IU} / 1(0-16480)$ and in the group 51-61 years, $154(14-292)$

Table 3. Rate of seroconversion ( $\geq 3$ IU/1) in the 217 trial participants after the first, second, and third dose of $\mathrm{HBsAg}$, stratified for groups A and B after the first injection (when double the dose of HBsAg was given in group B). There is no significant difference in the seroconversion rate between groups $A$ and $B$

\begin{tabular}{llll}
\hline & Group & $\begin{array}{l}\text { Conversion/ } \\
\text { immunized } \\
(n)\end{array}$ & Conversion \\
\hline First dose & A & $33 / 110$ & 30 \\
& B & $38 / 107$ & 36 \\
Second dose & Total & $71 / 217$ & 32.7 \\
Third dose & Total & $171 / 217$ & 78.8 \\
\hline
\end{tabular}

nonresponders were males. Twelve revaccinated participants remained low-responders.

No anamnestic responses were observed in six participants who were either anti-HBc or anti-HBs positive before vaccination.

\section{Sex}

The level of anti-HBs was dependent on the sex of the participants (Fig. 3). In females the geometric mean after the third injection was $1170 \mathrm{IU} / 1$

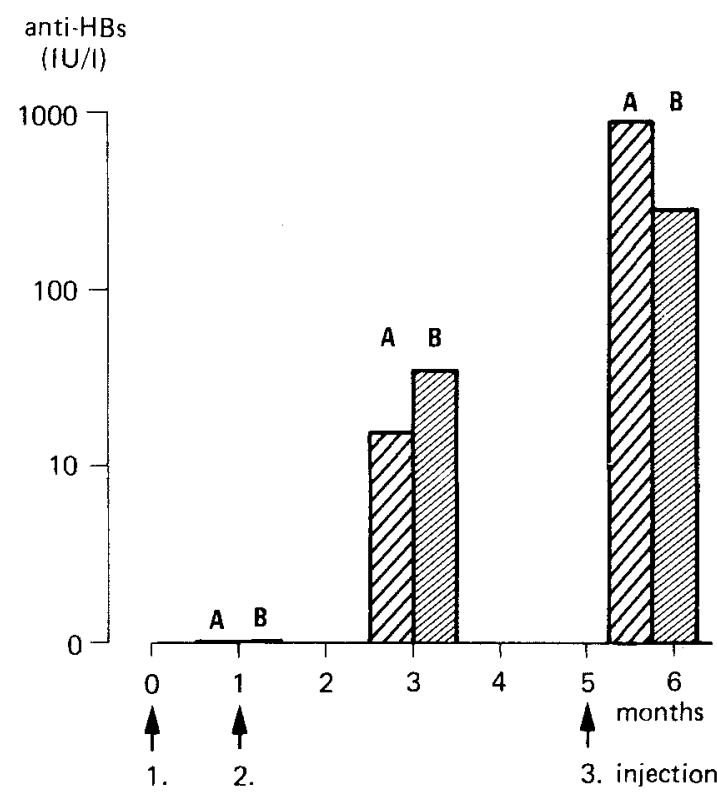

Fig. 5. Geometric means of anti-HBs, groups A and B. No significant difference after the first and second injection. The mean after the third injection for group A was $891 \mathrm{IU} / 1$ (range 0-51790); for group B, $278(0-137800)$. This difference is sta-

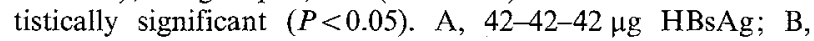
84-21-21 HBsAg

(range, 0-137800); in males, only $171(0-20000)$. This difference was statistically significant $(P<$ 0.002 ). No statistically significant differences between males and females were found, however, as far as the seroconversion rates after the first vaccination are concerned. The proportion of nonresponders and low-responders in males and females and the response to revaccination is described in the previous paragraph.

Age

The level of anti-HBs was also dependent on the age of the participants (Fig. 4). The younger the vaccine recipients were, the higher was the antiHBs titer produced after the third injection. In the age group 20-30 years, the geometric mean was $895 \mathrm{IU} / 1$ anti-HBs (range, $0-137800$ ); in the age group 31-40 years, $383 \mathrm{IU} / 1(0-49590)$; in the age group 41-50 years, $241 \mathrm{IU} / 1(0-16480)$; and in the age group of 51 years and older, $154 \mathrm{IU} / 1$ (14-2930). The differences between the age groups $20-30$ years and $31-40$ years and $20-30$ and $41-$ 50 years were statistically significant $(P<0.05)$. Higher age groups were too small to achieve statistical significance, but Fig. 4 clearly shows the trend to lower anti-HBs titers in the older age groups. 


\section{Variation of Dosage Schedule}

Compared with group A the higher dose of $\mathrm{HBs} A g$ in group B did not have an important effect on the seroconversion rate after the first injection (Table 3). It was $36 \%$ in group B and $30 \%$ in group A, a difference which was not statistically significant. The geometric mean of the anti-HBs titer after the third injection in group B was $278 \mathrm{IU} / 1(0-51790)$ and thus significantly $(P<0.05)$ lower than in group A with 891 IU/1 (0-137800) (Fig. 5).

\section{Adverse Effects}

Only minor side effects occurred. Almost $30 \%$ of the participants complained about soreness of the arm at the injection site. Other complaints were: rash at the injection site, pruritus and elevated body temperature, in a few cases only. All adverse effects resolved within 2-4 days.

\section{Discussion}

Safety aspects played an important part in the preparation of the German experimental vaccine used in this trial [25]. In order to reduce the theoretically possible residual infectivity, a high formalin concentration of 1:500 was used for inactivation [24]. This procedure for selection and inactivation of the experimental vaccine leads to changes in antigenicity and immunogenicity of the vaccine, which are lower than those of the MSD vaccine (HB-Vax). While the geometric mean of anti-HBs levels after the third injection was only $428 \mathrm{IU} / 1$ in our study, it is significantly higher when the MSD vaccine is used [28]. This is of practical importance in view of revaccination policy, since the initial anti-HBs titer was shown to predict the loss of protection after between 1 and 5 years [11]. As far as the seroconversion rates after the third injection are concerned, there is no difference between the experimental vaccine and the commercially available ones $[2,4,23]$.

In the context of our aim to study aspects of immunogenicity of HBsAg (such as genetic regulation of antibody response), the destruction of part of the antigenic epitopes may be of advantage. The detection of differences in genetic regulation could be facilitated, since it is well known that antibody responses are regulated on the single epitope level. As a consequence, compared with other studies $[2,5,10,12,21]$, we observe a relatively high percentage $(19 \%)$ of non- and low-responders and their immune system is now being studied.

It is interesting to note that in six individuals with either anti-HBc or anti-HBs positive sera no anamnestic response was observed, indicating that these "antibodies" were probably not related to previous infection with hepatitis B virus. It is thus important to immunize such persons.

One of the initial questions of our study was whether a modified immunization schedule with a higher first dose of $84 \mu \mathrm{g}$ and lower successive doses of $21 \mu \mathrm{g}$ would result in an earlier seroconversion. This was not the case. Seroconversion rates after the first injection were similar in groups A and B (Table 3). In another study, using dosages different from ours, no significant differences in the seroconversion rates were observed with doses of 40,20 , and $10 \mu \mathrm{g}$ HBsAg [10]. On the other hand, in this latter investigation, the levels of anti-HBs after the booster injection were dose-dependent. A 40- $\mu \mathrm{g}$ HBsAg dose resulted in higher anti-HBs titers than the 20- and 10- $\mu \mathrm{g}$ doses. This is in agreement with our findings that the anti-HBs levels after the third injection are lower with the dosage schedule 84-21-21 $\mu \mathrm{g}$.

The immune response depended on sex and age of the participants. Women acquired significantly higher anti-HBs levels, and the older the vaccinees were the lower were the anti-HBs titers after the booster injection. This was statistically significant between the age groups 20-31/31-40 and 20-30/41-50 years, and Fig. 4 clearly shows this trend for the other age groups as well. These findings are similar to those of other authors $[6,8$, $20,21,27]$, but only one author could demonstrate statistical significance [27]. Also, Wildgrube et al. [27] found a higher seroconversion rate in females and young vaccinees after the first injection, which we did not observe. Other studies have failed to demonstrate a dependency of the immune response on the sex of vaccinated health care workers [5] or Senegalese children [12].

Nonresponders and low-responders (participants who had anti-HBs titers below $50 \mathrm{IU} / 1$ after the third injection) received a fourth injection. It is known that a rapid decline in anti-HBs levels occurs within half a year after vaccination [11] and only persons with anti-HBs titers of $10 \mathrm{IU} / 1$ or higher are judged to be protected against hepatitis B. After the fourth injection, six of nine of the nonresponders acquired anti-HBs and all the lowresponders showed a higher anti-HBs level. In uremic patients with a high proportion of nonresponders more frequent injections also resulted in a higher seroconversion rate [1].

Only minor adverse effects were observed. Almost $30 \%$ of the participants complained about soreness of the arm at the injection site. Other side 
effects were a rash at the injection site, pruritus and temperature elevations, which were seen in a few cases only. Thus it can be concluded that the vaccine is safe and the adverse effects are similar to those after application of other vaccine preparations $[22,23,27]$.

Our results and other studies including experiments in mice $[9,13,14,15,16,26]$ suggest that responsiveness to hepatitis $B$ vaccine might be genetically determined, but a clear marker could not yet be elucidated in man. This may in part be due to small groups and unsophisticated methodology. We have observed a relatively large group of non- $/$ low-responders to HBsAg vaccination who are currently being screened for immune markers. This and the observed influence of sex and age will not only have practical consequences for revaccination policy but also offers the possibility to study the genetic regulation of an immune response to a complex peptide antigen in man. New modalities to circumvent a genetically determined low antibody response are already conceivable, such as immunization with pre-S antigens [7, 17], and this makes it more desirable to be able to predict the types of responders to conventional HBsAg vaccines.

Acknowledgements: Our thanks are due to Prof. R. Thomssen, Hygiene-Institut der Universität Göttingen, for providing us with the vaccine and performing the radioimmunoassays for detection of anti-HBs titers. We are also indebted to D. Klüssendorf for supporting us in the statistical evaluation of the data, to Mrs. A. Lottmann for technical assistance, and to Mrs. M. Göritz for organizational help. Part of this work was presented at the 19th meeting of the European Association for the Study of the Liver (EASL), Bern 1984 [19].

\section{References}

1. Bommer J, Deinhardt F, Jilg W, Darai D, Andrassy K, Ritz E (1983) Impfung urämischer Patienten gegen Hepatitis B. Dtsch Med Wochenschr 108:1823-1826

2. Crosnier J, Jungers P, Courouce A-M, Laplanche A, Benhamou E, Degos F, Lacour B, Prunet P, Cerisier Y, Guesry $P$ (1981) Randomised placebo-controlled trial of hepatitis B surface antigen vaccine in French hemodialysis units: I. Medical staff. Lancet I 455:459

3. Crosnier J, Jungers P, Courouce A-M. Laplanche A, Benhamou E, Degos F, Lacour B, Prunet P, Cerisier Y, Guesry $P$ (1981) Randomised placebo-controlled trial of hepatitis B surface antigen vaccine in French hemodialysis units: II. Hemodialysis patients. Lancet I:797-800

4. Dienstag JL, Ryan DM (1982) Occupational exposure to hepatitis $B$ virus in hospital personnel: infection or immunization? Am J Epidemiol 115:26-39

5. Dienstag JL, Werner BG, Polk F, Snydman DR, Craven DE, Platt R, Crumpacker CS, Oullet-Hellstrom R, Grady GF (1984) Hepatitis B vaccine in health care personnel: safety, immunogenicity, and indicators of safety. Ann Intern Med 101:34-40
6. Guesry PR, Adamowicz P, Jungers P, Couroucé A-M, Laplanche A, Lacour B, Benhamou E, Degos F, Crosnier J (1982) Vaccination against hepatitis B in high-risk hemodialysis units. A double-blind study. In: Szmuness W, Alter HJ, Maynard JE (eds) Viral hepatitis, Franklin Institute Press, Philadelphia, pp 493-507

7. Heermann KH, Kruse F, Gerlich WH (1986) Immunogenität der Prä-S Domänen des Hepatitis B-Virus. Z Gastroenterol 24:19-20

8. Henning H, Laufs R, Kätzner K, Bredehorst R (1983) Ergebnisse einer aktiven Schutzimpfung gegen die Hepatitis B mit deutschem Impfstoff. Z Gastroenterol 21:111-114

9. Höher PG, Vögeler U, Schröder G, Werner J, Doxiadis I, Grosse-Wilde H (1983) Correlation between immunogenetic markers and "in-vivo" response to the German hepatitis B vaccine. Devel biol Stand 54:171-178

10. Hollinger FB, Adam E, Heiberg D, Melnick JL (1982) Response to hepatitis $B$ vaccine in a young adult population. In: Szmuness W, Alter HJ, Maynard JE (eds) Viral hepatitis, Franklin Instutute Press, Philadelphia, 451-466

11. Jilg W, Schmidt M, Zachoval R, Deinhardt F (1985) Persistenz von Antikörpern gegen Hepatitis B-Oberflächenantigene nach Impfung gegen Hepatitis B. Dtsch Med Wochenschr 110:205-209

12. Maupas $\mathrm{P}$, Chiron J-P, Barin F, Coursaget P, Goudeau A, Perrin J, Denis F, Diop Mar, I (1981) Efficacy of hepatitis $\mathrm{B}$ vaccine in prevention of early $\mathrm{HBsAg}$ carrier state in children, controlled trial in an endemic area (Senegal). Lancet I:289-292

13. Milich DR, Chisari FV (1982) Genetic regulation of the immune response to hepatitis B surface antigen (HBsAg). I. $\mathrm{H}-2$ restriction of the murine humoral immune response to the $\mathrm{a}$ and $\mathrm{d}$ determinants of HBsAg. J Immunol $129: 320-325$

14. Milich DR, Leroux-Roels GG, Chisari FV (1983a) Genetic regulation of the immune response to hepatitis $B$ surface antigen (HBsAg). II. Qualitative characteristics of the humoral immune response to the $\mathrm{a}, \mathrm{d}$ and $\mathrm{y}$ determinants of HBsAg. J Immunol 3:1395-1400

15. Milich DR, Alexander H, Chisari FV (1983 b) Genetic regulation of the immune response to hepatitis $B$ surface antigen (HBsAg). III. Circumvention of nonresponsiveness in mice bearing HBsAg nonresponder haplotypes. J Immunol 2:1401-1407

16. Milich DR, Leroux-Roels GG, Louie RE, Chisari FV (1984) Genetic regulation of the immune response to hepatitis B surface antigen ( $\mathrm{HBsAg}$ ). IV. Distinct H-2-linked Ir genes control antibody responses to different HBsAg determinants on the same molecule and map to the I-A and I-C subregions. J Exp Med 159:41-56

17. Neurath AR, Kent SBH, Strick N, Stark D, Sproul P (1985) Genetic restriction of immune responsiveness to synthetic peptides corresponding to sequences in the pre-S region of the hepatitis B virus (HBV) envelope gene. J Med Virol 17:119-125

18. Reerink-Brongers EE, Reesink HW, Brummelhuis HGJ, Schut BJTh, Dees PJ, Lelie PN, Raap AK, Wilson-deStürler LA, van Aken WG, Balner $H$, van Eerd PMCA, van Schie ThC, Stitze LW, van Steenis B, Feltkamp Vroom ThM (1982) Preparation and evaluation of heat-inactivated HBsAg as a vaccine against hepatitis B. In: Szmuness W, Alter HJ, Maynard JE (eds) Viral hepatitis. Franklin Institute Press, Philadelphia, pp 437-450

19. Sommer D, Krämer A, Hahn EG, Riecken EO (1985) Sex and age differences in anti-HBs-titers after active immunization against hepatitis B. J Hepatol [Suppl.] 1: S 132

20. Stevens CE, Alters HJ, Taylor PE, Zang EA, Harley EJ, 
Szmuness W and the Dialysis Vaccine Trial Study Group (1984) Hepatitis B vaccine in patients receiving hemodialysis, immunogenicity and efficacy. $N$ Engl $J$ Med $311: 496-501$

21. Szmuness W, Stevens CE, Harley E, Zang EA, Taylor PE, Alter HJ (1981a) The immune response of healthy adults to a reduced dose of hepatitis B vaccine. J Med Virol $8: 123-129$

22. Szmuness W, Stevens CE, Zang EA, Harley EJ, Kellner A (1981 b) A controlled clinical trial of the efficacy of the hapatitis B vaccine (Hepatavax B): a final report. Hepatology $1: 377-385$

23. Szmuness W, Stevens CE, Harley EJ, Zang EA, Alter HJ, Taylor PE, DeVera A, Chen GTS, Kellner A and the Dialysis Vaccine Trial Study Group (1982) Hepatitis B vaccine in medical staff of hemodialysis units. $N$ Engl $\mathrm{J}$ Med $307: 1481-1486$

24. Thomssen R, Gerlich W, Boettcher U, Stibbe W, Legler $\mathrm{K}$, Weinmann E, Klinge O, Pfeiffer U (1982) Herstellung und Erprobung eines Hepatitis B-Impfstoffes. Dtsch Med Wochenschr 107:125-131

25. Thomssen R, Gerlich W, Boettcher U, Legler K, Ritter S, Stibbe W, Weinmann W, Klinge O, Pfeifer U (1983) Safety and potency aspects in the preparation of an experimental HBsAg vaccine. Devel Biol Stand 54:23-31
26. Walker ME, Szmuness W, Stevens CE, Rubinstein P (1981) Genetics of anti-HBs responsiveness: I. HLA-DR7 and non-responsiveness to hepatitis vaccination (abstract) Transfusion $21: 601$

27. Wildgrube HJ, Classen M, von Lohr R, Kurth R, Brede HD (1984) Aktive Immunisierung gegen Virushepatitis B. Dtsch Med Wochenschr 109:246-250

28. Zoulek G, Jilg E, Deinhardt F (1983) Immunprophylaxe der Hepatitis B. 3. Ergebnisse klinischer Studien mit Hepatitis B-Impfstoffen. Dtsch Med Wochenschr 108:1123-1129

Received: August 7, 1985

Returned for revision: September 16, 1985

Accepted : February 20, 1986

Dr. A. Krämer

Medizinische Klinik und Poliklinik mit

Schwerpunkt Gastroenterologie

Klinikum Steglitz der Freien Universität

Hindenburgdamm 30

1000 Berlin 45 